\title{
Vessel Traffic Control Strategy under Complex Weather Conditions for Three Gorges Reservoir
}

\author{
Yaojie Chen ${ }^{1,2, *} \quad$ Liwen Huang ${ }^{1,2}$ \\ ${ }^{1}$ Hubei Key Laboratory of Inland Shipping Technology, Wuhan 430063, China \\ ${ }^{2}$ School of Navigation, Wuhan University of Technology, Wuhan 430063, China \\ *378831830@qq.com
}

Key words: Three Gorges reservoir, complex weather, safety distance, safety speed, vessel traffic control

Abstract: To ease ship traffic overstock and accidents caused by complex weather in Three Gorges reservoir, the paper took ship traffic organization as the research object. Combined with the features of inland navigation, the paper built up both the safety distance model and safe model for Three Gorges reservoir under complicated weather conditions, which would provide references for safety distance and safety speed control. On the above basis, the paper put forward the specific vessel traffic control strategy including ship speed limit, dynamic ship monitoring, etc., to ensure ship navigation safety and improve management skills under complex weather conditions in Three Gorges reservoir.

\section{Introduction}

In recent years, with the development of western economy and Yangtze River Golden Waterway in China, vessel traffic flow is increasing massively in the Three Gorges Reservoir channel. Ship backlog results from the Three Gorge shiplock's "out of service" due to complex weather conditions including fog, strong wind, etc. What is more, complex weather conditionsoften cause maritime accidents and (or) dangerous situations, which can be seen by analysising vessel traffic accident statistics.

In view of bad influence on navigation efficiency and safety caused by complex weather, numerous scholars have studied the ship navigation security technologies for Three Gorges Reservoir and reached some achievements. However, the present studies focus on: (1) analysising characteristics of the complex weather [1-3], (2) risk analysis and assessment of navigation environment [4-7], (3) early warning mechanism for complex weather [8,9], and maritime emergency management $[11,12]$, there is little studies taking vessel traffic control technology as the theme of research. In this paper, vessel traffic control strategy in Three Gorges Reservoir will be treated as the subject, ship safety speed limit, safety distance limit, etc. will be discussed and recommended, combined with the constraint conditions for ship safety under abnormal weather and microscopic traffic flow theories. The research aims to provide theoretical and technical support for developing vessel traffic management measures for Three Gorges Reservoir under abnormal weather conditions.

\section{Ship safety distance control}

Under certain traffic environment, a ship is required to keep certain speedand a safedistance $h$ with rear ship for safety navigation. The goal of safe distance $h$ and safe time $t$ is in order to ensure that the 
ship had enough time to take proper and effective action to avoid collision and stopped the ship in the safe distance.

Due to the Three Gorges Reservoir routing system has been implemented and the middle and lower of YangtzeRiver have implemented traffic separation rules, so we can use ship follow state to derive safety distance.

To ensure the safety of navigation, the driver alwaysmake the worst prepare about the in front of ship, that is the in front of the ship will suddenly slow down or malfunctioning. We assumed two ships before and after traveling speed is equal, the safety distance should be the minimum distance that can ensure when the before ship have emergency braking or failure, but the after boat have not the collision danger.Fig. 1 shows the braking process of the later ship for safety.

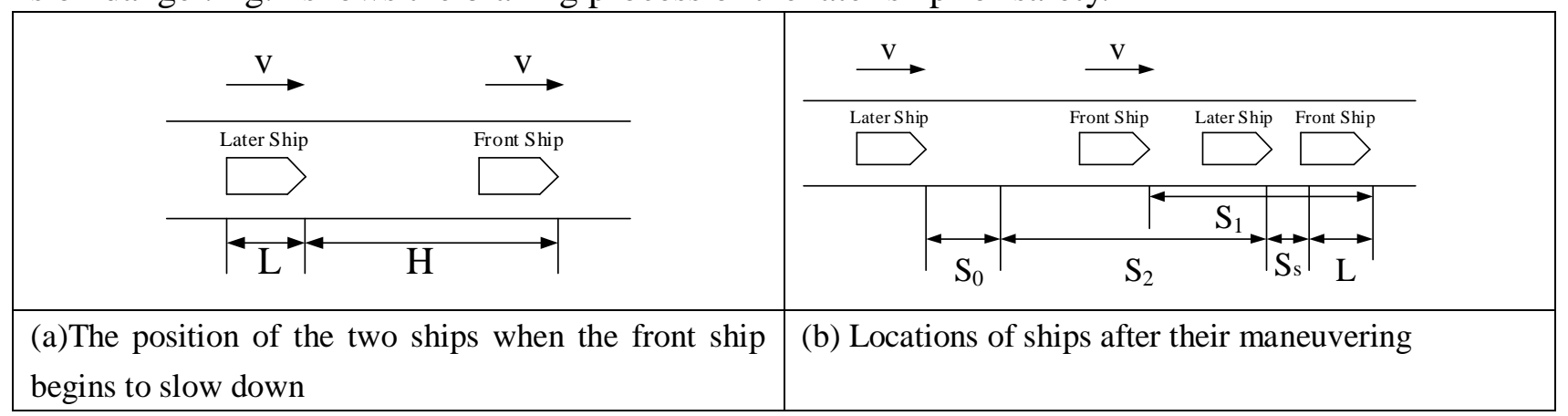

Fig. 1.The braking process of the later ship for safety

The expression of safe distance can be obtained from Fig.1:

$$
\mathrm{H}=\mathrm{l}+\mathrm{S}_{\mathrm{s}}+\mathrm{S}_{2}+\mathrm{S}_{0}-\mathrm{S}_{1}(1)
$$

In formula(1): $\mathbf{h}$ stands for safe distance $(\mathrm{m})$; l represents standardized captain $(\mathrm{m})$, the values depend on the tonnage of the ship.Ss is safe stopping distance, which shall not be less than $80 \mathrm{~m}$ according to the provisions of the Yangtze River Maritime Bureau; $S_{0}$ is the glide distance of the later ship whenthe front ship has been found $(\mathrm{m}) ; \mathrm{S} 0=v t ; \mathrm{S}_{2}$ is the later ship's reversing stroke; $\mathrm{S} 1$ is the front ship's reversing stroke; $\mathbf{v}$ is ships traveling speed; tis Driver's reaction time when the visibility suddenly reduced, It is hard to the driver to adapt to this change, so under the most unfavorable conditions we take $\mathrm{t}$ as $2 \mathrm{~min}$.

Conclusion can be drawnfrom expressions (1) that safe distance have a closed relationship with the sailing speed, reaction time,braking time between two ships and otherfactors.Consider the more rational conditions, weset the same two ships brakingperformance, which means $\mathrm{S} 1=\mathrm{S} 2$.

And the safety distance relationship becomes:

$$
\mathrm{H}=\mathrm{L}+\mathrm{S}_{\mathrm{s}}+\mathrm{vt}
$$

\section{Vessel traffic control method under complicated weather conditions}

Complex weather meanswhat have bad impacts on thetraffic safety. According to the different weather, it can be divided into two categories, one is the weather only affects effective visibility SD, such as fog, rain, snow early and so on; The second category refers to the impact of the ship maneuverability limitations caused by water conditions, mainly include strong wind weather.

\section{Safe distance control}

Under the first kind of weather conditions, it will causethe driver effective sight distance $\mathrm{S}_{\mathrm{D}}$ shortened. In order to keep traffic safety,we need to increase the perception reaction time $\mathbf{t}$ and adjust the pitch and speed of ships. In this case of traffic safety control, the constraints are classifiedas: 
(1) When a valid ship safety distance SD is far more than the horizon $\mathrm{h}$, the driver necessary perception reaction time $\mathbf{t}$ need to fixed, and adjust the speed $\mathrm{V}$ to make ship distance $\mathrm{H}$ satisfy:

$H \geq h(3)$

Whereh $=\mathrm{L}+\mathrm{S}_{\mathrm{s}}+\mathrm{vt}_{1}, \mathrm{t}_{1}$ is reduced visibility due to weather shortens.

(2)When the effective horizon $S_{D}$ spacing is less than the safety distance of the ships $\mathbf{h}$, In order to ensure the safety of traffic condition like this: Boats driver need to master the dynamic of the front ship to ensure that boat driver have enough time and safe distanceto take corresponding measures ,when unexpected situation occurs. Thus in this case, it is need to adjust the speed vto satisfy traffic safety control model of variable constraint.

$$
S_{D} \geq H \geq h-L_{S}
$$

Where $L_{S}$ is reduced visibilityresult in the driver effectively $S_{D}$ horizon shortened, and the amendments to ship safe distance is $h, h=L+S_{\mathrm{s}}+v t_{1}$.

\section{Safe speed control}

Considering the safe speed is the ship appropriate speed at that moment, it is too fast, or too slow is not the safe speed. That means in the same waters, a ship speed may be a safe speed while another ship is at the same speed or low-speed may be unsafe speed. Therefore, the selection of safe speed ship should be determined by the ship's own situation and the navigable environment.

\section{Safe speed under the first kind of weather conditions}

In caseof weather conditions, when the effective horizon $\mathbf{S}_{\mathbf{D}}$ less than the safety distance $\mathbf{h}$, we see the effective horizon $\mathbf{S}_{\mathbf{D}}$ as safe distance, and draw the appropriate speed of the ship as a safe speed limit. Which is

$$
S_{D}=h=L+k S_{\mathrm{s}}+v t_{1}(5)
$$

Where, vis the vessel's speed(kn);t is the driver's reaction time. In case ofpoor visibility, the corrected time ist $\mathbf{t}_{\mathbf{1}}$, and the driver's reaction time after the correction value of $2 \mathrm{~min} ; \mathbf{L}$ is the total length of the ship, unit $\mathrm{m} ; S_{\mathrm{s}}$ is safe stopping distance, unit $\mathbf{m} ; \mathbf{k}$ isthe correction coefficient under poor visibility conditions for safe distance, which ranges from 1 to 8 , we generally take 4 as in the inland situation.

The safe limit speed of the ship can be calculated

$$
v=\left(S_{D}-L-k S_{\mathrm{s}}\right) / t 1
$$

Ship speed limit values under different visibility conditions can be calculated by formula (6), as shown in Table 3. 
Table 1. Ship speed limit values under different visibility conditions

\begin{tabular}{|c|c|c|c|c|c|}
\hline \multicolumn{3}{|l|}{$\frac{\text { Visibility }}{\text { Ship Status }}$} & \multicolumn{3}{|c|}{ Visibility } \\
\hline Ship types & Tonnage & Length & $1000 \mathrm{~m}$ & $500 \mathrm{~m}$ & $200 \mathrm{~m}$ \\
\hline \multirow{2}{*}{ Bulk cargo } & 5000 Ton & $110 \mathrm{~m}$ & $9.5 \mathrm{kn}$ & $1.2 \mathrm{kn}$ & Prohibit sailing \\
\hline & 3000 Ton & $95 \mathrm{~m}$ & $9.7 \mathrm{kn}$ & $1.4 \mathrm{kn}$ & Prohibit sailing \\
\hline \multirow{2}{*}{ Liquid cargo } & 3500 Ton & $100 \mathrm{~m}$ & $9.6 \mathrm{kn}$ & $1.3 \mathrm{kn}$ & Prohibit sailing \\
\hline & 1000 Ton & $75 \mathrm{~m}$ & $10 \mathrm{kn}$ & $1.8 \mathrm{kn}$ & Prohibit sailing \\
\hline \multirow{2}{*}{ Ro-Ro } & $\begin{array}{l}\text { roll-on/roll-off } \\
\text { (70-110 seats) }\end{array}$ & \multirow{2}{*}{$110 \mathrm{~m}$} & \multirow{2}{*}{$9.5 \mathrm{kn}$} & \multirow{2}{*}{$1.2 \mathrm{kn}$} & \multirow{2}{*}{ Prohibit sailing } \\
\hline & $\begin{array}{l}\text { Ro-Ro } \\
(300-800 \text { seats })\end{array}$ & & & & \\
\hline \multirow{2}{*}{ Container } & 350TEU & $110 \mathrm{~m}$ & $9.5 \mathrm{kn}$ & $1.2 \mathrm{kn}$ & Prohibit sailing \\
\hline & 200TEU & $90 \mathrm{~m}$ & $9.8 \mathrm{kn}$ & $1.5 \mathrm{kn}$ & Prohibit sailing \\
\hline
\end{tabular}

\section{Safe speed under the second kind of weather conditions}

Ship speed limit aims to avoid serious sway,water on deck and the ship slap phenomenon in big storm.Refers to speed calculate method that allowed in the large sea waves, we propose speed design formulas under river big storm as follows:

$$
V_{a}=V_{0}[1-(m / L+N)]
$$

In the formulas (7): $\mathrm{V}_{\mathrm{a}}$ is the allowed speed in thelarge waves, $\mathrm{V}_{0}$ is ship design speed, $\mathrm{L}$ is the length of the ship, $\mathrm{m} 、 \mathrm{~N}$ are the parameterswhose value can be taken in Table 4 .

Table 2.Allowed parameter under high waves

\begin{tabular}{|c|l|l|l|l|l|l|l|l|}
\hline \multirow{2}{*}{$\begin{array}{c}\text { Beaufort } \\
\text { wind scale }\end{array}$} & \multicolumn{2}{|c|}{ Top Lang } & \multicolumn{2}{c|}{ Slant wave } & \multicolumn{2}{c|}{ Transverse wave } & \multicolumn{2}{c|}{ Shun oblique wave } \\
\cline { 2 - 9 } & $\mathrm{m}$ & $\mathrm{N}$ & $\mathrm{m}$ & $\mathrm{N}$ & $\mathrm{m}$ & $\mathrm{N}$ & $\mathrm{m}$ & $\mathrm{N}$ \\
\hline 5 & 9 & 0.02 & 7 & 0.02 & 3.5 & 0.01 & 1 & 0 \\
\hline 6 & 13 & 0.06 & 10 & 0.05 & 5.0 & 0.03 & 2 & 0.01 \\
\hline 7 & 21 & 0.11 & 14 & 0.08 & 7.0 & 0.05 & 4 & 0.02 \\
\hline 8 & 36 & 0.18 & 23 & 0.12 & 10.0 & 0.07 & 7 & 0.03 \\
\hline
\end{tabular}

The ship allowed speed under different winds can be derived from formula (4). And the allowed safety speed value the least favorable condition that ship takes top wave sailing.

Specific limit values shown in Table 5.

Table 3. Allowed speed under different winds

\begin{tabular}{|c|c|c|c|c|c|c|c|}
\hline \multirow{2}{*}{\multicolumn{4}{|c|}{$\begin{array}{l}\text { Beaufort wind scale } \\
\text { The maximum safe speed }\end{array}$}} & \multirow{2}{*}{\multicolumn{4}{|c|}{ Beaufort wind scale }} \\
\hline & & & & & & & \\
\hline Ship types & Tonnage & Length & Designed speed & 5 & 6 & 7 & 8 \\
\hline \multirow{2}{*}{ Bulk cargo } & 5000Ton & $110 \mathrm{~m}$ & \multirow{2}{*}{$9.7 \mathrm{kn}$} & $8.7 \mathrm{kn}$ & $8.0 \mathrm{kn}$ & $6.8 \mathrm{kn}$ & $4.8 \mathrm{kn}$ \\
\hline & 3000 Ton & $95 \mathrm{~m}$ & & $8.6 \mathrm{kn}$ & $7.8 \mathrm{kn}$ & $6.5 \mathrm{kn}$ & $4.3 \mathrm{kn}$ \\
\hline \multirow{2}{*}{ Liquid cargo } & 3500 Ton & $100 \mathrm{~m}$ & \multirow{2}{*}{$9.7 \mathrm{kn}$} & $8.6 \mathrm{kn}$ & $7.9 \mathrm{kn}$ & $6.6 \mathrm{kn}$ & $4.5 \mathrm{kn}$ \\
\hline & 1000 Ton & $75 \mathrm{~m}$ & & $8.3 \mathrm{kn}$ & $7.4 \mathrm{kn}$ & $5.9 \mathrm{kn}$ & $3.3 \mathrm{kn}$ \\
\hline Ro-Ro & roll-on/roll-off & $110 \mathrm{~m}$ & $11.3 \mathrm{kn}$ & $10.1 \mathrm{kn}$ & $9.3 \mathrm{kn}$ & $7.9 \mathrm{kn}$ & $5.6 \mathrm{kn}$ \\
\hline
\end{tabular}




\begin{tabular}{|c|c|c|c|c|c|c|c|}
\hline & $(70-110$ seats $)$ & & & & & & \\
\hline & $\begin{array}{l}\text { Ro-Ro } \\
(300-800 \text { seats })\end{array}$ & & & & & & \\
\hline \multirow{2}{*}{ Container } & 350TEU & $110 \mathrm{~m}$ & \multirow{2}{*}{$10.8 \mathrm{kn}$} & $9.7 \mathrm{kn}$ & $8.9 \mathrm{kn}$ & $7.6 \mathrm{kn}$ & $5.3 \mathrm{kn}$ \\
\hline & 200TEU & $90 \mathrm{~m}$ & & $9.5 \mathrm{kn}$ & $8.6 \mathrm{kn}$ & $7.1 \mathrm{kn}$ & $4.5 \mathrm{kn}$ \\
\hline \multirow{3}{*}{ Passenger } & 330 seats & $45 \mathrm{~m}$ & $13.5 \mathrm{kn}$ & $10.5 \mathrm{kn}$ & $8.8 \mathrm{kn}$ & $5.7 \mathrm{kn}$ & $0.3 \mathrm{kn}$ \\
\hline & 460 seats & $76 \mathrm{~m}$ & \multirow{2}{*}{$14.6 \mathrm{kn}$} & $12.6 \mathrm{kn}$ & $11.2 \mathrm{kn}$ & $9.0 \mathrm{kn}$ & $5.1 \mathrm{kn}$ \\
\hline & 670 seats & $87 \mathrm{~m}$ & & $12.8 \mathrm{kn}$ & $11.5 \mathrm{kn}$ & $9.5 \mathrm{kn}$ & $5.9 \mathrm{kn}$ \\
\hline
\end{tabular}

\section{Vessel traffic flow control under complex weather conditions}

We use the ship safety distance $\mathrm{H}$, safety sailing time $\mathrm{T}$ and speed $\mathrm{V}$ to descriptmicrostates waterway traffic flow.There is a relationship between traffic flow variables $\mathrm{H}=\mathrm{VT}$. In this equation, any two can be used as an argument, the other one as the dependent variable. The ship safe time can be calculated base on the safe speed, resulting in the waters traffic flow.

$$
\begin{array}{r}
T=H / V \\
Q=3600 / T
\end{array}
$$

In formula (9), $\mathrm{T}$ is the safe speed betweenthe two ships; $\mathrm{H}$ is the safe distance, $\mathrm{V}$ corresponds to the maximum safe speed in the visible conditions; $Q$ is the flow of ships under the current weather conditions.

Ship traffic limit under different visibilityis shown in Table 6.

\begin{tabular}{|c|c|c|c|c|}
\hline $\begin{array}{l}\text { Ship } \\
\text { types }\end{array}$ & Tonnage & $\operatorname{Visibility}(\mathrm{m})$ & $\begin{array}{c}\text { Themaximum safe } \\
\text { speed }(\mathrm{kn})\end{array}$ & $\begin{array}{c}\text { Shiptraffic flow } \\
\text { (ships/h) }\end{array}$ \\
\hline \multirow{4}{*}{ Bulk cargo } & \multirow{2}{*}{ 5000Ton } & 1000 & 9.5 & 17 \\
\hline & & 500 & 1.2 & 4 \\
\hline & \multirow{2}{*}{3000 Ton } & 1000 & 9.7 & 17 \\
\hline & & 500 & 1.4 & 5 \\
\hline \multirow{4}{*}{$\begin{array}{l}\text { Liquid car- } \\
\text { go }\end{array}$} & \multirow{2}{*}{3500 Ton } & 1000 & 9.6 & 17 \\
\hline & & 500 & 1.3 & 4 \\
\hline & \multirow{2}{*}{1000 Ton } & 1000 & 10 & 18 \\
\hline & & 500 & 1.8 & 6 \\
\hline \multirow{2}{*}{ Ro-Ro } & $\begin{array}{l}\text { roll-on/roll-off } \\
(70-110 \text { seats })\end{array}$ & 1000 & 9.5 & 17 \\
\hline & $\begin{array}{c}\text { Ro-Ro } \\
(300-800 \text { seats })\end{array}$ & 500 & 1.2 & 4 \\
\hline \multirow{4}{*}{$\begin{array}{l}\text { Contain- } \\
\text { er }\end{array}$} & \multirow{2}{*}{ 350TEU } & 1000 & 9.5 & 17 \\
\hline & & 500 & 1.2 & 4 \\
\hline & \multirow{2}{*}{ 200TEU } & 1000 & 9.8 & 18 \\
\hline & & 500 & 1.5 & 5 \\
\hline
\end{tabular}

Table 4.Ship traffic limit under different visibility 


\section{Vessel traffic control strategy under complex weather conditions}

\section{Limiting speed}

Depending on the security models, we calculate the speed limit values about dry bulk carriers, tankers, ro-ro, container ships and cruise ships sail under different wind and visibility conditions, listed in Table 7.

Table 5.Ships limit speed in different weather conditions

\begin{tabular}{|l|c|c|c|c|c|c|c|c|}
\hline $\begin{array}{c}\text { Weather } \\
\text { Speed Lipit } \\
\text { Ship types }\end{array}$ & \multicolumn{4}{|c|}{$\begin{array}{c}\text { I class weather conditions } \\
\text { Poor visibility }(\mathrm{m})\end{array}$} & $>1500$ & 1000 & 500 & \multicolumn{2}{|c|}{$\begin{array}{l}\text { II class weather conditions } \\
\text { Big waves weather }\end{array}$} \\
\cline { 2 - 10 } & Any & $9.5 \mathrm{kn}$ & $1.2 \mathrm{kn}$ & $\begin{array}{c}\text { Prohibit } \\
\text { navigation }\end{array}$ & $8.2 \mathrm{kn}$ & $7.3 \mathrm{kn}$ & $5.6 \mathrm{kn}$ & $2.8 \mathrm{kn}$ \\
\hline Bulk cargo & Areeze & $\begin{array}{c}\text { Strong } \\
\text { breeze }\end{array}$ & $\begin{array}{c}\text { Moderate } \\
\text { gale }\end{array}$ & $\begin{array}{c}\text { Fresh } \\
\text { gale }\end{array}$ \\
\hline Liquid cargo & Any & $9.6 \mathrm{kn}$ & $\begin{array}{c}\text { Prohibit } \\
\text { navigation }\end{array}$ & $\begin{array}{c}\text { Prohibit } \\
\text { navigation }\end{array}$ & $8 \mathrm{kn}$ & $6.9 \mathrm{kn}$ & $5.1 \mathrm{kn}$ & $1.9 \mathrm{kn}$ \\
\hline Ro-Ro & Any & $9.5 \mathrm{kn}$ & $1.1 \mathrm{kn}$ & $\begin{array}{c}\text { Prohibit } \\
\text { navigation }\end{array}$ & $10.1 \mathrm{kn}$ & $9.3 \mathrm{kn}$ & $7.9 \mathrm{kn}$ & $5.6 \mathrm{kn}$ \\
\hline Container & Any & $9.5 \mathrm{kn}$ & $1.2 \mathrm{kn}$ & $\begin{array}{c}\text { Prohibit } \\
\text { navigation }\end{array}$ & $9.3 \mathrm{kn}$ & $8.3 \mathrm{kn}$ & $6.6 \mathrm{kn}$ & $3.7 \mathrm{kn}$ \\
\hline Passenger & Any & $9.8 \mathrm{kn}$ & $\begin{array}{c}\text { Prohibit } \\
\text { navigation }\end{array}$ & $\begin{array}{c}\text { Prohibit } \\
\text { navigation }\end{array}$ & $10.5 \mathrm{kn}$ & $8.8 \mathrm{kn}$ & $5.7 \mathrm{kn}$ & $0.3 \mathrm{kn}$ \\
\hline
\end{tabular}

Based on the above analysis, traffic management strategies can be developed under complicated weather conditions:

(1) In the case of poor visibility, when the visibility is less than $1500 \mathrm{~m}$, taking ship speed restrictions, prohibiting visibility tankers and cruise ships sail below $500 \mathrm{~m}$. When the visibility is less than $200 \mathrm{~m}$, prohibiting all vessels navigable.

(2) when in windy weather conditionsas the wind above 5 degree, speed restrictions measure should be taken. Taking into account the large wind relative area of container ships and ro-roly and the influence of navigation and cargo security by wind is obvious, so when the wind reached more than degree,we prohibit container vessels and ro-ro ships sailing.In order to protect the ship navigation safety, we should ban all ships sailing when wind above 8 degree.

\section{Monitoring}

Because of the uncertainty of the weather, it is difficult for driver toadjust the safety sailing speed and distance timely. It is easily to have an accident without taking effective action. Depending on the impact that weather conditions have, we can take reasonable traffic control strategy, level management and a special one-way segments, also can enhance on-site supervision, so as to mitigate the effects of weather. Traffic management strategies in complex weather conditions shown in Table 8. 
Table 6.Vessel traffic monitor strategy under fog

\begin{tabular}{|c|c|c|c|c|c|}
\hline $\begin{array}{l}\text { Traffic } \\
\text { Safety }\end{array}$ & $\begin{array}{l}\text { Visibility } \\
\text { (m) }\end{array}$ & $\begin{array}{l}\text { Traffic } \\
\text { Flow }\end{array}$ & Regulatory Policy & $\begin{array}{l}\text { Traffic } \\
\text { control }\end{array}$ & Preventive measures \\
\hline \multirow{4}{*}{$\begin{array}{l}\text { No ac- } \\
\text { cide-nts }\end{array}$} & $>1000$ & $\begin{array}{l}\text { Normal } \\
\text { Crowded } \\
\text { Lag }\end{array}$ & $\begin{array}{l}\text { Warning deceleration, Reminded to } \\
\text { keepa proper look } \\
\text { Speed limit, To draw attention to traffic } \\
\text { safety } \\
\text { Speed limit, warned ahead Lag }\end{array}$ & 19ships/h & $\begin{array}{l}\text { Timely weather warn- } \\
\text { ing information re- } \\
\text { lease, Step up patrols }\end{array}$ \\
\hline & $500 \sim 1000$ & $\begin{array}{l}\text { Normal } \\
\text { Crowded } \\
\text { Lag }\end{array}$ & $\begin{array}{l}\text { Speed limit, Posted fog warning, Pay } \\
\text { attention to the safety of navigation } \\
\text { Speed limit, Posted fog warning, Keep } \\
\text { the ship pitch } \\
\text { Speed limit, Posted fog warning, Assist } \\
\text { ship diversion }\end{array}$ & $\begin{array}{l}17 \text { ships } \\
\text { /h }\end{array}$ & $\begin{array}{l}\text { Strengthening site } \\
\text { supervision, } \\
\text { Cooperative Vessel } \\
\text { Traffic Organization }\end{array}$ \\
\hline & $200 \sim 500$ & $\begin{array}{l}\text { Normal } \\
\text { Crowded } \\
\text { Lag }\end{array}$ & $\begin{array}{l}\text { Speed limit, Posted fog warning, } \\
\text { Control of Ship Traffic } \\
\text { Speed limit, Posted fog warning, Assist } \\
\text { ship diversion } \\
\text { Posted fog warning, Anchoring and } \\
\text { berthing arrangements for vessels }\end{array}$ & 7 ships /h & $\begin{array}{l}\text { Coast Guard boats } \\
\text { deployed on-site du- } \\
\text { ty, Ships moored tie } \\
\text { matte organization }\end{array}$ \\
\hline & $<200$ & $\begin{array}{l}\text { Normal } \\
\text { Crowded } \\
\text { Lag }\end{array}$ & $\begin{array}{l}\text { Speed limit, Posted fog warning and } \\
\text { suspended info, } \\
\text { Vessel Traffic Organization, Vessel Traf- } \\
\text { fic ban } \\
\text { Traffic control, Post closure navigation } \\
\text { information. }\end{array}$ & Blockage & $\begin{array}{l}\text { Firefighting, maritime } \\
\text { travel on high alert, } \\
\text { ready to go to imple- } \\
\text { ment emergency. }\end{array}$ \\
\hline \multirow{2}{*}{ Accide-nts } & $>1000$ & $\begin{array}{l}\text { Normal } \\
\text { Crowded } \\
\text { Lag }\end{array}$ & $\begin{array}{l}\text { Post navigational notices, Inform Acci- } \\
\text { dents properties, Deceleration Inform } \\
\text { Accidents properties, Tips shunt } \\
\text { Speed limit, Post navigational notices, } \\
\text { Temporary traffic control }\end{array}$ & $\begin{array}{l}19 \text { ships } \\
\text { /h }\end{array}$ & $\begin{array}{l}\text { Fire, Marine accor- } \\
\text { dance with their re- } \\
\text { spective responsibili- } \\
\text { ties deal with the ac- } \\
\text { cident scene, and di- } \\
\text { recting passing ships } \\
\text { navigation }\end{array}$ \\
\hline & $<1000$ & $\begin{array}{l}\text { Normal } \\
\text { Crowded } \\
\text { Lag }\end{array}$ & $\begin{array}{l}\text { Speed limit, Inform Accidents properties } \\
\text { Tips shunt } \\
\text { Speed limit, Inform Accidents proper- } \\
\text { ties, Control of Ship Traffic } \\
\text { Traffic control, Tips to choose the right } \\
\text { anchor waters }\end{array}$ & $\begin{array}{l}17 \text { ships } \\
\text { /h }\end{array}$ & $\begin{array}{l}\text { Fire, Marine deal with } \\
\text { the accident scene } \\
\text { according to their re- } \\
\text { spective responsibili- } \\
\text { ties, maintain naviga- } \\
\text { tion safety, emergency } \\
\text { preparedness }\end{array}$ \\
\hline
\end{tabular}




\section{Conclusions}

In view of the complex weather's influences on water transportation in Three Gorges Reservoir, ship safety speed limit, safety distance limit, etc. were discussed and recommended in this paper, combined with theconstraint conditions for ship safety under abnormal weather and microscopic traffic flow theories. Further, vessel traffic control strategy under complex weather conditionsin Three Gorges Reservoir were propose. The research can provide theoretical and technical support for developing vessel traffic management measures for Three Gorges Reservoir under abnormal weather conditions.

\section{Acknowledgement}

The research was sponsored by the Fund of Hubei Inland Shipping Technology Key Laboratory (NO NHHY2014001) and the grants from the Key Project in the National Science \& Technology Pillar Program (GrantNo.2015BAG20B05).

\section{References}

[1]Sun Shixing, Qin Chengping, Ju Zhigang. Climatic features in Three Gorges dam area[J]. CHINA THREE GORGES CONSTRUCTION,2006,24(3):22-24.

[2]Wang Zhong, Chen Yanying. Analysison Shipping Meteorological Conditionsinthe Three Gorges Reservior Area[J]. RESOURCES AND ENVIRONMENT IN THE YANGTZE BASIN, 2008,17(1):79-82.

[3]Chen Xianyan, Zhang Qiang, Ye Dianying.Regional Climate Changeover Three Gorges Reservoir Area[J]. RESOURCES AND ENVIRONMENT IN THE YANGTZE BASIN,2009,18(1):47-51.

[4]Wang Yanfeng, Li Hongxiang.Research on navigable environment risk identification of Three Gorges reservoirarea [J]. Journal of Wuhan Institute of Shipbuilding Technology, 2012, (4):14-17.

[5]Mou Xiaoping. Research on navigation environment safety evaluation of Three Gorges reservoir area [D]. Dalian Marine University, 2009.

[6]Zhou Yanping. Safety Evaluation of Navigation Environment in Adjoining Waters of Bridges Over Three Gorges Reservoir Area [D]. Dalian Marine University, 2010.

[7]Ma Lili, Wu Chaozhong, Chen Gang, et al. The Navigable Environment Safety Fuzzy Comprehensive Evaluation Model and Its Application of Three Gorges Reservoir [J]. SHIP \& OCEAN ENGINEERING, 2009.4, 38(2):141-144.

[8]Xu Kaijin.Study of waterborne safety early warning management based on the crisis management[J]. TRANSPORTATION SCIENCE \& TECHNOLOGY, 2005(04): 124-125.

[9]Li Hongjiu.Analysis of the Mechanism of Early-warning and Expedient Management in Emergency of the Three Gorges Reservoir Region[J].Journal of Wuhan University of Technology (Social Sciences Edition), 2006(01):114-117.

[10]Xiong Bing, Zhang Shiyu.On early warning management mechanism of Three Gorges navigation in fog[J]. SHIPPING MANAGEMENT,2009,31(9):36-38.

[11]Xiong Bing. Study on WaterTransport Safety Control and Emergency Management for Three Gorges Reservoir of Yangtze River [D]. Wuhan University of Technology, 2011.

[12] Yuan Zongxiang. Research on Water Traffic Safety Supervision and Emergency Response for Three Gorges Reservoir Area [D]. Wuhan University of Technology, 2012. 